\title{
Données récentes sur la maturation des spermatozoïdes dans l'épididyme humain
}

\author{
Trevor G. COOPER \\ Institute of reproductive Medicine of the University, Münster Domagkstrabe 11 D-48129 Münster GERMANY
}

Traduction française : Jean François GUÉRIN

\section{RÉSUMÉ}

Au cours de leur transit épididymaire, les spermatozoïdes rencontrent un environnement varié, au regard des protéines avec lesquelles ils rentrent en contact. Dans la partie proximale de l'épididyme, ils sont soumis à l'action d'enzymes, et exposés à des protéines susceptibles de modifier les membranes. Dans la partie moyenne prédomine une autre catégorie de protéines et d'enzymes ; celles associées au transport de stérols pourraient modifier les membranes spermatiques afin de permettre l'ancrage de protéines de liaison à la zone pellucide : $\mathbf{P}$ 34H et CD52. Dans la partie distale les spermatozoïdes rencontrent des activités croissantes d'enzymes lytiques, des protéines impliquées à la fois dans la liaison à la zone pellucidé et la fusion ovocytaire, l'antigène de maturation $C D 52$, une activité anti-microbienne, et enfin des agents décapacitants qui facilitent leur survie avant l'éjaculation. L'adhérence des protéines aux différents domaines membranaires (comme la région antérieure ou le segment équatorial de l'acrosome) peut dépendre de la nature de la protéine, de la composition lipidique de la région membranaire concernée, et de l'environnement ionique dans la lumière épididymaire. La localisation des protéines sur le spermatozoïde, qu'il soit à acrosome intact (membrane acrosomique) ou acrosome-réagi (segment équatorial) pourra dicter leur rôle, concernant par exemple la fixation à la zona (P 34H), ou la liaison à l'ovocyte (gp 20). Les protéines comme les membranes peuvent être modifiées durant le transit épididymaire par des enzymes qui peuvent ajouter ou retirer des sucres et des peptides de la surface spermatique.

Mots clés : maturation des spermatozoïdes, épididyme humain, protéines épididymaires

\section{INTRODUCTION}

Les succès obtenus dans les ICSI avec spermatozoïdes extraits du testicule, peuvent donner l'impression que l'épididyme n'est pas nécessaire au processus de fécondation, mais ce raisonnement est faux [7]. Les difficultés à disposer d'épididymes humains intacts, l'impossibilité de pratiquer des biopsies sur un canal unique [45] ont certainement retardé la recherche sur cet organe comparée à celle sur le testicule. Néanmoins, on a pu utiliser du tissu à partir d'autopsies, de victimes d'accidents, d'opérations pour carcinome prostatique, prostatectomie radicale et transplantation. La complexité de la tête épididymaire humaine [50] et les incertitudes quant à la région précise d'où le fragment est extrait dans beaucoup d'études, ne contribuent pas à clarifier la situation. Néanmoins, les données cumulées (présentées ici graphiquement et sous forme de tableaux) révèlent un profil de maturation non différent de celui trouvé dans d'autre espèces qui ont été mieux étudiées. Cette revue résume les informations relatives aux changements concernant les spermatozoïdes au cours de leur maturation dans l'épididyme humain.

On en connaît moins, même chez l'animal, sur le mécanisme par lequel l'épididyme influence la maturation des spermatozoïdes. L'application des techniques de biologie moléculaire à l'épididyme humain au cours de la dernière décennie, a complété les travaux antérieurs sur des protéines spécifiques $[14,15]$. Il ressort à l'évidence de cette littérature que les spermatozoïdes sont soumis à un environnement qui change en permanence dans l'épididyme, et

Correspondance :

Trevor G. Cooper, Institute of Reproductive Medicine of the University, Münster, Domagkstraße 11, D-48129 Münster, Germany

Tel: +49-251-8352045 ; Fax: +49-251-8356093 ; e-mail: cooper@uni-muenster.de Communication au XVIII' Congrès de la Société d'Andrologie de Langue Française, Montpellier, 13-15 décembre 2001. 
rentrent séquentiellement en contact avec des protéines qui ont le potentiel de modifier les interactions spermatozoïdesovocytes.

\section{MATURATION SPERMATIQUE DANS L'ÉPIDIDYME HUMAIN}

\section{Morphologie}

Si on soumet des spermatozoïdes humains épididymaires aux mêmes procédures que les spermatozoïdes éjaculés pour apprécier la morphologie, il en résulte un gonflement artéfactuel de nombreux spermatozoïdes de la région de la tête, mais pas de celle de la queue [47, 52]. Ces changements dans la capacité à résister à l'assèchement avant fixation a constitué une démonstration inattendue de modifications de maturation qui semblent affecter les spermatozoïdes de primates [22]. Le pourcentage de têtes spermatiques «normales » augmente ainsi au cours de la maturation (Fig. 1a), non pas comme le résultat de l'élimination de cellules anormales, mais par l'apparition d'un type cellulaire plus résistant. Les dimensions de têtes de spermatozoïdes non gonflés varient également au cours de la maturation, elles deviennent plus petites (Fig. $1 \mathrm{~b}$ ).

Ce rétrécissement cellulaire peut refléter la déshydratation causée par l'osmolarité élevée du fluide épididymaire, mais on connait peu de chose chez l'homme. Haidl et al. [25] ont suggéré que la morphologie spermatique anormale est en relation avec une dysfonction épididymaire.

\section{Mobilité}

Les spermatozoïdes obtenus à partir de spermatocèles épididymaires (représentant le fluide testiculaire piégé à l'intérieur des canaux efférents borgnes : Cooper et al., [9]) sont mobiles, comme ceux prélevés dans la tête épididymaire. Le pourcentage de spermatozoïdes mobiles (estimé subjectivement une fois transférés dans un milieu adéquat), augmente au cours du transit, mais chez les hommes âgés examinés, une chute de la mobilité a été observée dans la queue (Fig. 1c). Ceci est censé refléter la population vieillissante de spermatozoïdes stockés, qui n'avaient pas été « vidangés » chez les hommes âgés. L'analyse du mouvement assistée par ordinateur révèle une amélioration de la vélocité et de la linéarité des trajectoires (Fig. 1c). La vélocité des spermatozoïdes extraits du corps de l'épididyme, est aussi élevée que celles des spermatozoïdes éjaculés d'hommes plus jeunes, attestant du fonctionnement normal du processus de maturation chez ces patients.

L'initiation de la mobilité peut être un phénomène dépendant du temps, plutôt que due aux sécrétions épididymaires, puisque des spermatozoïdes extraits du testicule ou de la tête épididymaire sont mobiles seulement dans des cas d'obstruction [30,38], que des spermatozoïdes obtenus par biopsie testiculaire deviennent mobiles au bout d'un certain temps d'incubation [13].

\section{Liaison à la zone pellucide (ZP)}

Les premières données concernant la capacité de liaison des spermatozoïdes humains épididymaires à la zone pellucide, n'ont pas montré de différence avec les spermatozoïdes éjaculés [10, 20], (Fig 1d). Il semble que ce soit dû aux conditions non physiologiques du protocole (température basse pour réduire la vélocité des spermatozoïdes les plus matures, afin d'éliminer le biais représenté par un plus grand nombre de collisions avec l'ovocyte) ; en fait, la réalisation de conditions capacitantes révèle une différence nette entre les spermatozoïdes de la tête, incapables de se lier à la zone pellucide, et les spermatozoïdes éjaculés ou de la queue de l'épididyme, qui le peuvent (Fig. 1d). Ce sont les protéines épididymaires qui ont été impliquées dans la capacité de liaison à la zone pellucide (cf Tableau 1).

\section{Réaction acrosomique (RA)}

La ZP constitue un stimulateur de la RA (fusion de la membrane plasmique et de la membrane acrosomale externe, et perte des vésicules ainsi formées). En l'absence de grandes quantités de ZP humaines disponibles, un ionophore calcique a été utilisé pour induire la RA. Le pourcentage de spermatozoïdes épididymaires ayant effectué spontanément la RA est élevé, mais similaire dans toutes les régions de l'épididyme (Fig.le). La réponse à l'ionophore est cependant plus élevée pour les spermatozoïdes de la queue que pour ceux du corps, tandis que les spermatozoïdes de la tête ne répondent pas du tout (Fig. le). Un changement dans la réponse des spermatozoïdes à l'influx calcique est clairement observé, ce qui conditionne leur capacité à faire la RA.

Les protéines épididymaires liant les stérols et les lipides (cf. table 1) sont capables de rendre les membranes plus fluides, ce qui constitue un pré-requis pour la vésiculisation acrosomique. Chez l'homme, une dysfonction épididymaire a été associée à une rigidité anormalement élevée de la membrane spermatique [54].

\section{Contenu en acrosine}

L'acrosine, enzyme protéolytique contenue dans l'acrosome, est libérée, et la fraction liée exposée sur la membrane acrosomale interne après la RA. La quantité d'acrosine dans la tête a été mesurée à partir de la surface d'un film de gélatine, qui est digéré par l'enzyme libérée par les spermatozoïdes fixés sur le film (Fig. If. Une petite surface ainsi digérée est observée autour des têtes spermatiques plus matures [26], mais ceci peut indiquer un passage de la forme soluble à la forme liée de l'acrosine, plutôt qu'une perte d'enzyme ou d'activité.

\section{Liaison avec la membrane ovocytaire et fusion}

Les spermatozoïdes capacités et ayant effectué la RA peuvent se lier et éventuellement fusionner avec la membrane ovocytaire après avoir traversé la ZP. En utilisant le 

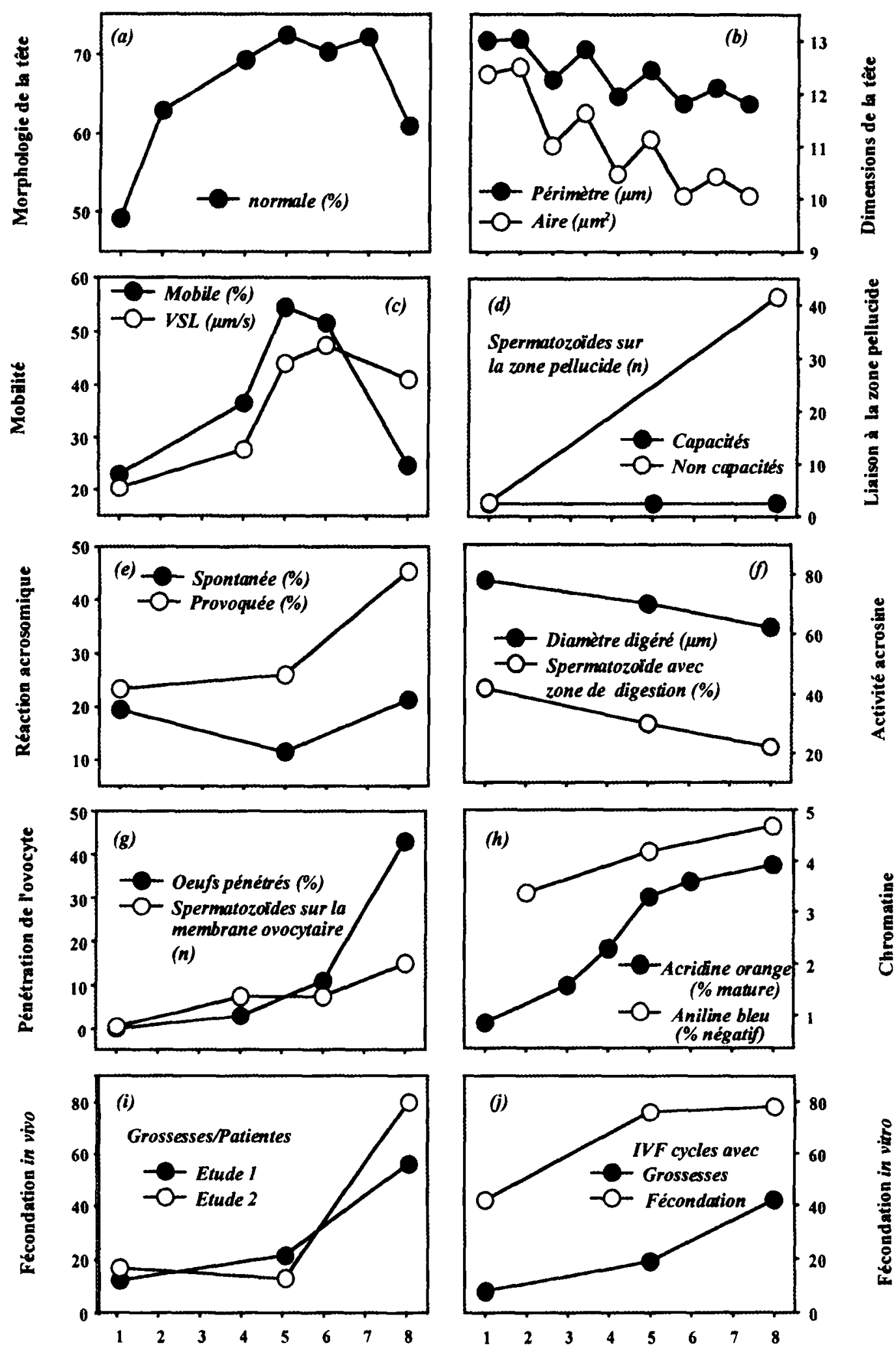

Régions de l'épididyme

Figure 1 : Maturation des spermatozoïdes dans l'épididyme humain. Différents paramètres fonctionnels (en ordonnées) sont rapportés en fonction de la région épididymaire (en abscisses : 1 : canaux efférents ; 2 : corps proximal : 3 : limite entre parties proximale et moyenne du corps ; $4:$ corps moyen : 5 : corps distal ; 6 : limite entre parties distale du corps et proximale de la queue ; $7:$ queue proximale ; 8 : queue distale). (a) forme normales [47]; (b) morphométrie de la tête spermatique [47]; (c) mobilité et vélocité [51] ; (d) : liaison à la zona $[10,39]$; (e) réaction acrosomique [52]; $(f)$ contenu en acrosine [26] ; $(g)$ fusion gamétique [40] ; (h) condensation chromatinienne [23, $26]$; (i) capacité fécondante après épididymo-vasostomie $[19,46]$; (j) fécondation in vitro [4I]. 
Tableau 1 : Protéines testiculaires et épididymaire humaines semblant impliquées dans la liaison des spermatozoüdes humains à la zone pellucide / la penetration intraovocytaire et la mobilité.
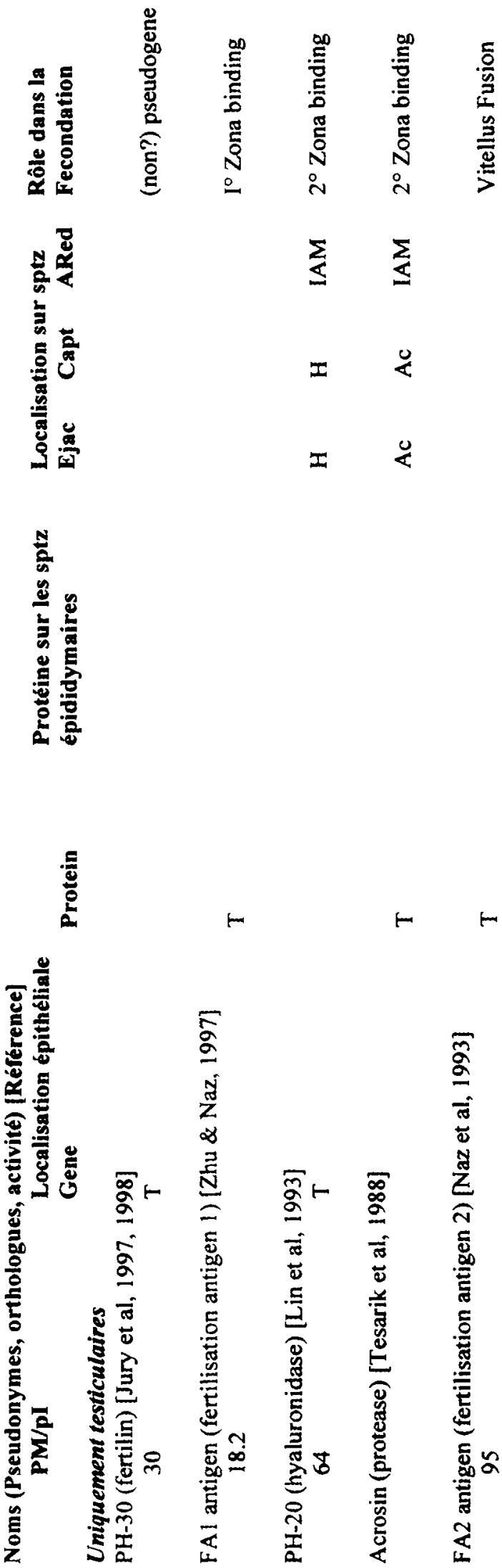

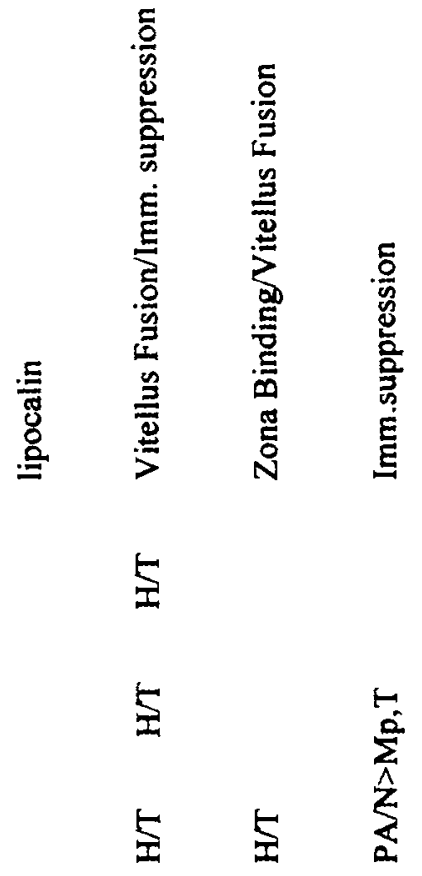

$\otimes$

E.

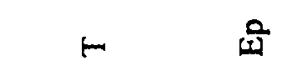

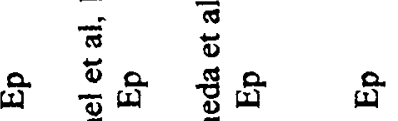

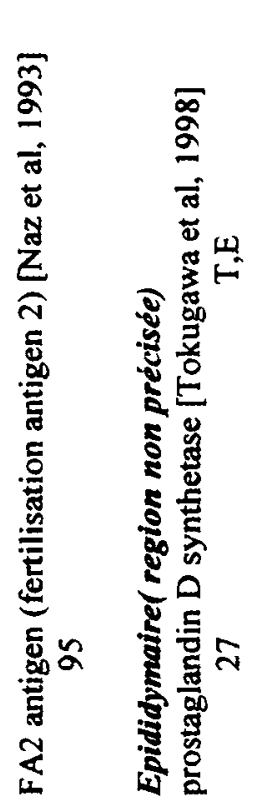

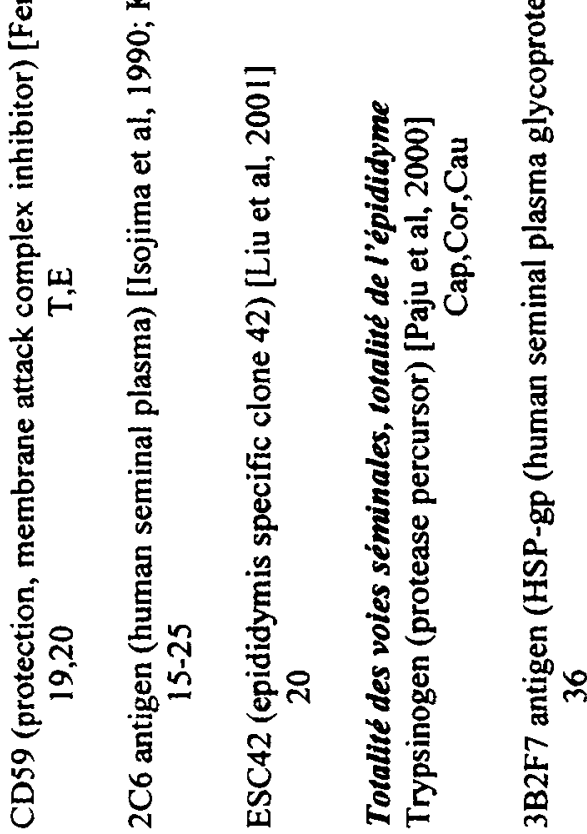

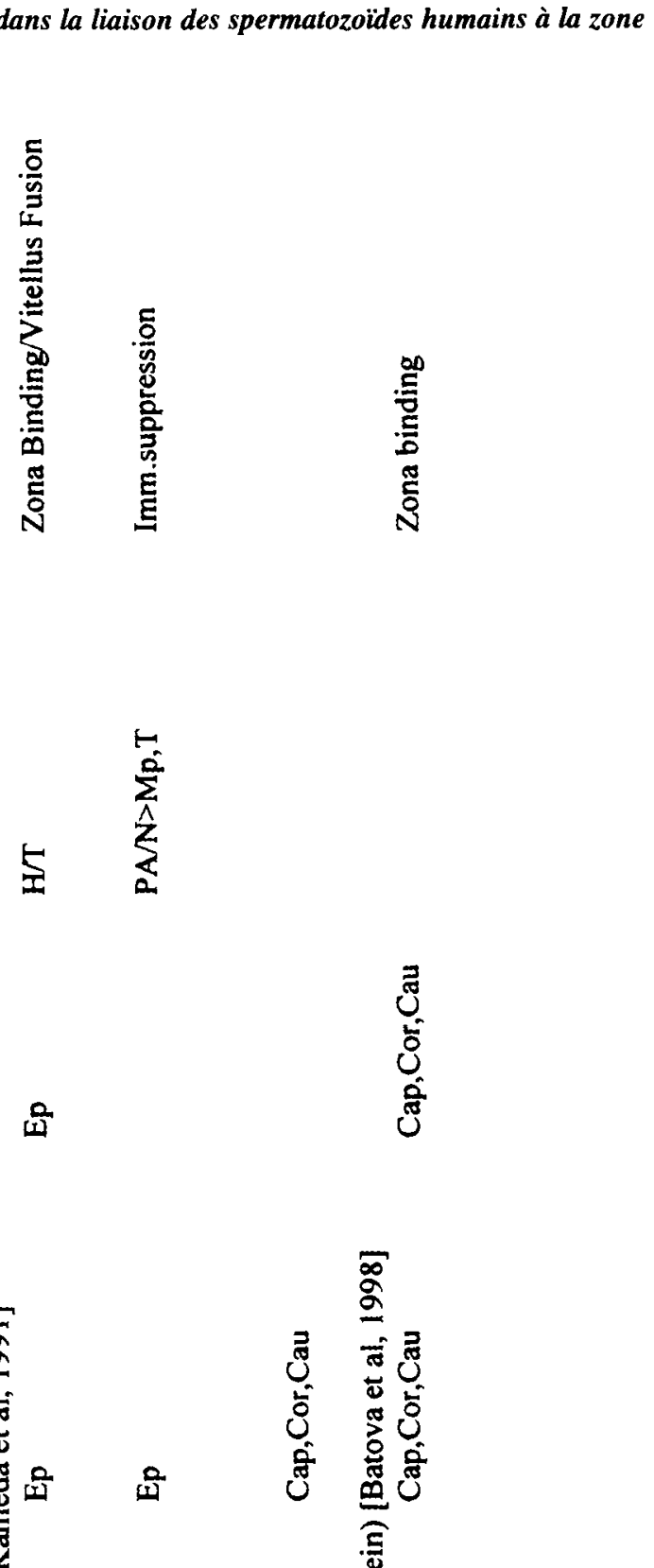

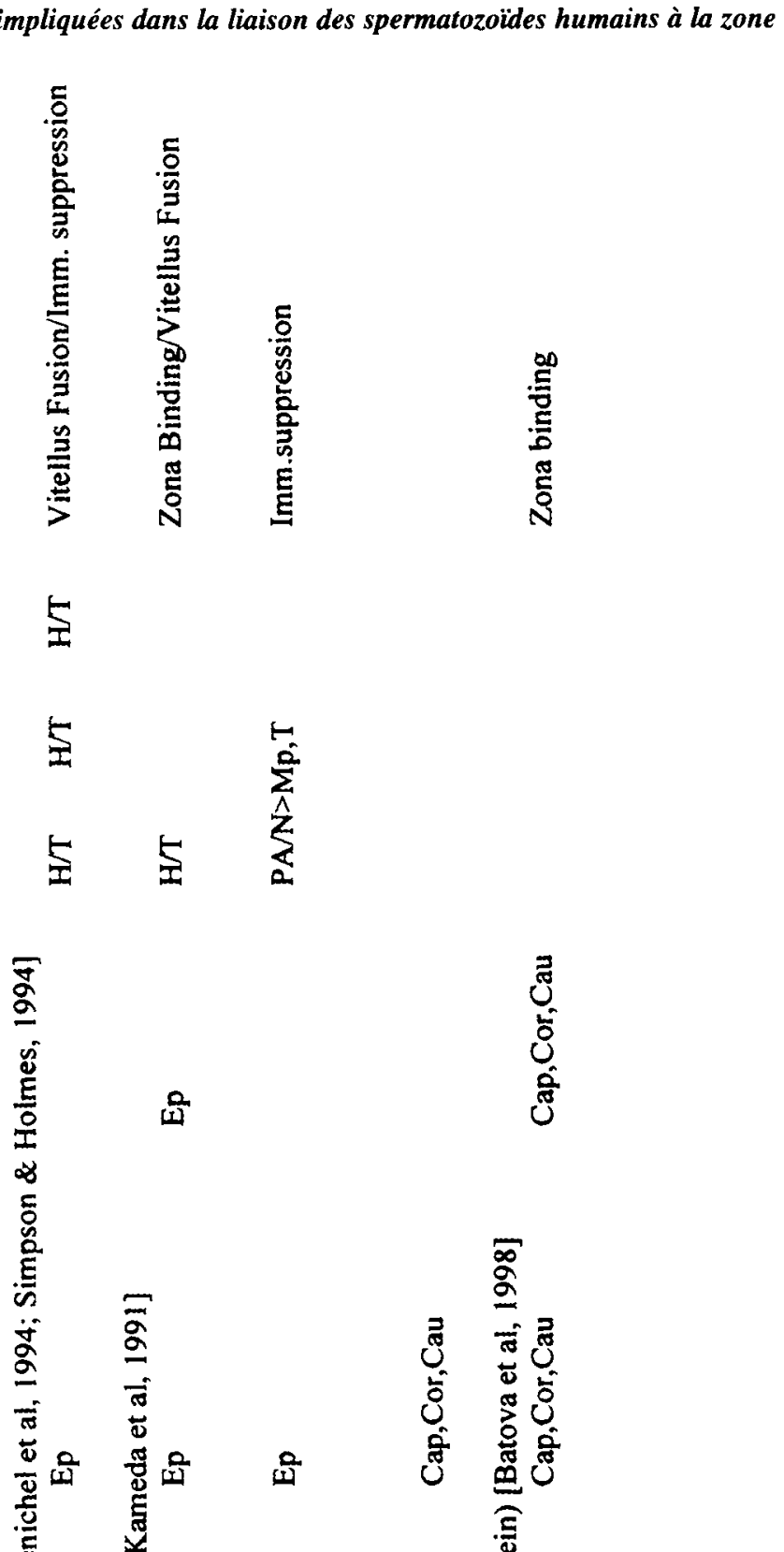

只<smiles>C1CCCCC1</smiles>

离 
Tableau 1 : Protéines testiculaires et épididymaire humaines semblant impliquées dans la liaison des spermatozoïdes humains à la zone pellucide / la penetration intraovocytaire et la mobilité.

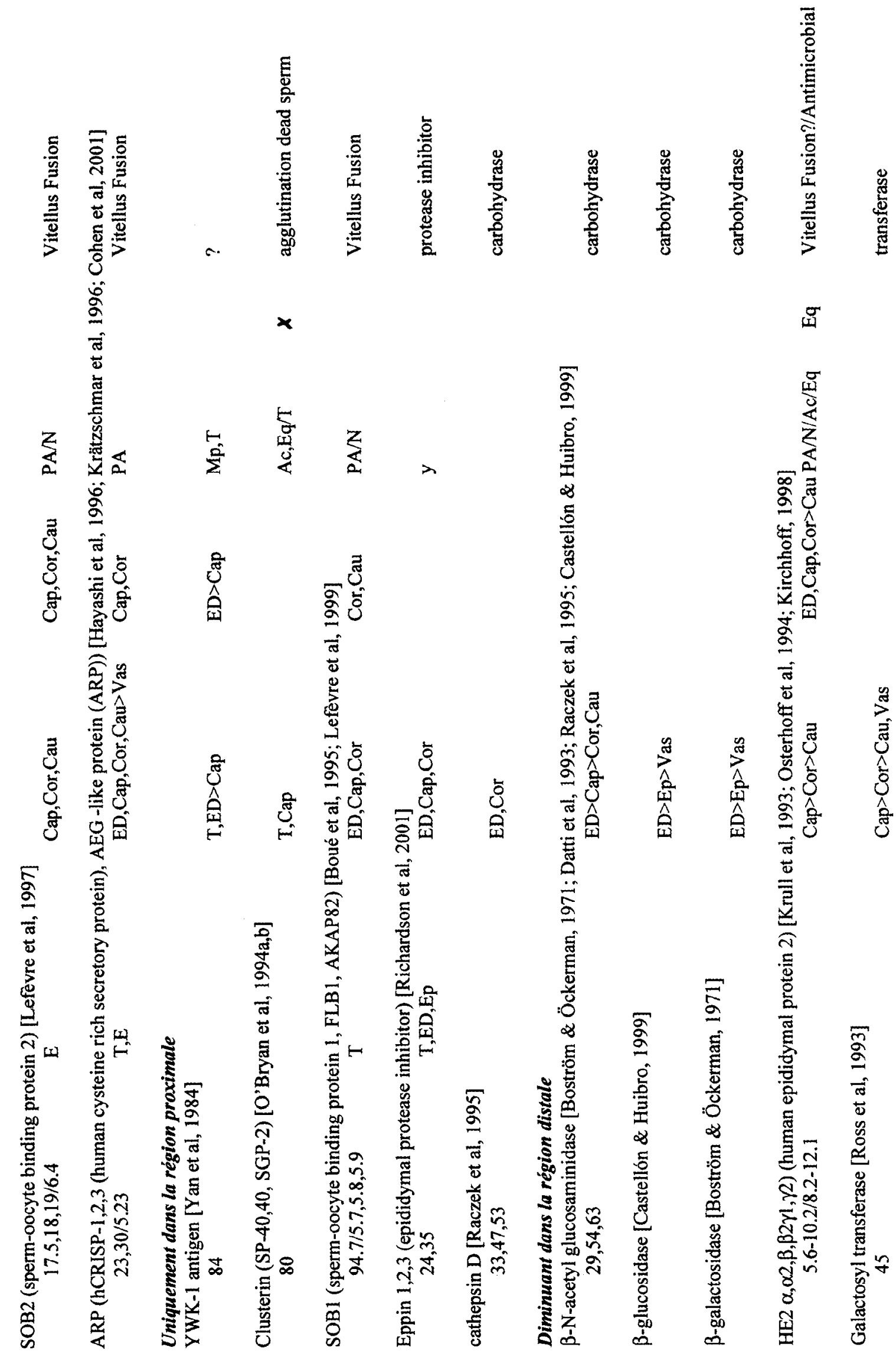



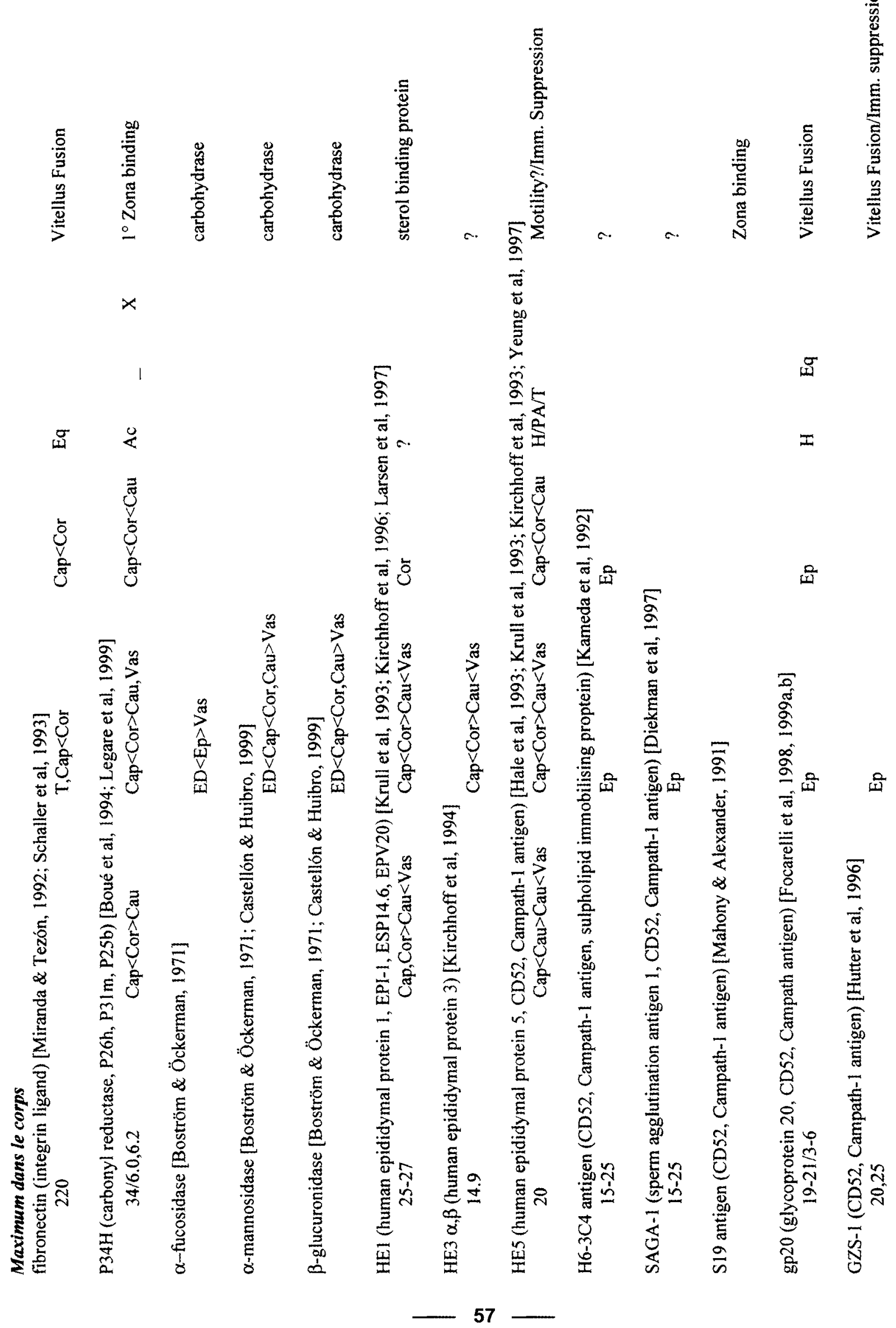

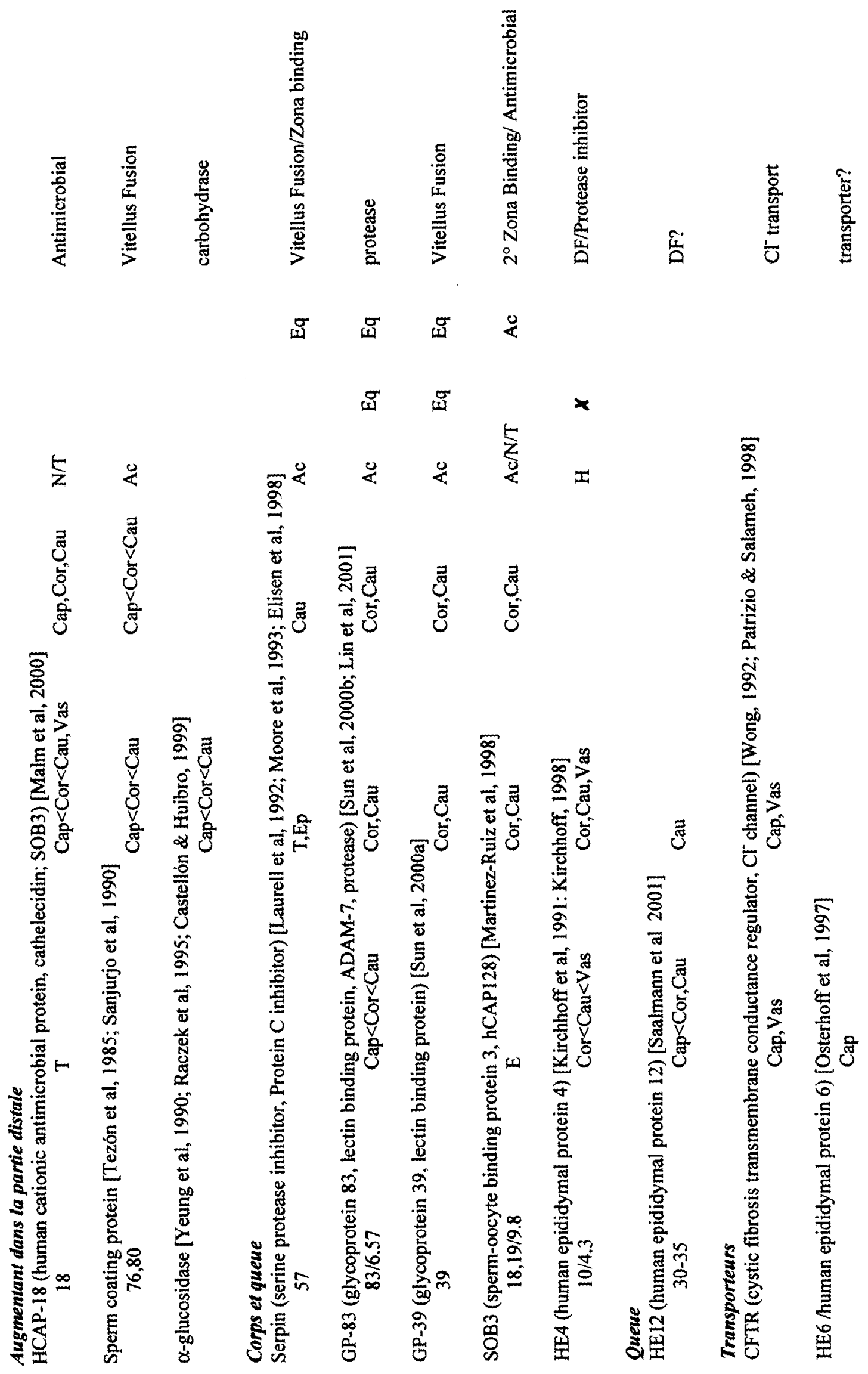
$\Uparrow$ augmentation ; 8 : absent $; ?:$ inconnu $; 1^{\circ}$ : primaire $; 2^{\circ}:$ secondaire ; Ac : acrosome ; Ared : spermatozoïdes acrosome réagi ; Capt : spermatozoïde capacité ; Cap (Caput) : Tête épididymaire ; Cau (cauda): queue épididumaire ; Cor, corps épididymaire ; $\mathrm{E}$ : epididyme ; Ed (efferent ducts) : canaux efferents ; Ejac : spermatozoïdes ejaculés ; Ep : région épididymaire non précisée ; Eq, equatorial ; $\mathrm{H}$ (head): Tête entière ; IAM (inner acrosomal membrane) : membrane acrosomique interne ; $\mathrm{Mp}$ (midpiece) : pièce intermédiaire ; $\mathrm{N}$ (neck): col ; PA : post-acrosomique ; $\mathrm{T}$ (tail) : flagelle ; $\mathrm{T}$ : testicule ; Vas : canal deferens ; y : présent, region non précisée.

\section{References}

Batova, I. N., Ivanova, M. D., Mollova, M. V. \& Kyurkchiev, S. D. (1998) Human sperm surface glycoprotein involved in human spermzona pellucida interaction. Int J Androl, 21, 141-153.

Bostrom, K. \& Ockerman, P. A. (1971) Glycosidases in human semen and male genital organs. Scand J Urol Nephrol, 5, 117-122.

Boué, F., Berube, B., De Lamirande, E., Gagnon, C. \& Sullivan, R. (1994) Human sperm-zona pellucida interaction in inhibited by an antiserum against a hamster sperm protein. Biol Reprod, 51, 577-587.

Boué, F., Duquenne, C., Lassalle, B., Lefèvre, A. \& Finaz, C. (1995) FLB1, a human protein of epididymal origin that is involved in the sperm-oocyte recognition process. Biol Reprod, 52, 267-278.

Castellón, E. A. \& Huidobro, C. C. (1999) Androgen regulation of glycosidase secretion in epithelial cell cultures from human epididymis. Human Reprod. 14, 1522-1527.

Cohen, D. J., Ellerman, D. A., Busso, D., Morgenfeld, M. M., Piazza, A. D., Hayashi, M., Young, E. T., Kasahara, M. \& Cuasnicú, P. S. (2001) Evidence that human epididymal protein ARP plays a role in gamete fusion through complementary sites on the surface of the human egg. Biol Reprod, 65, 1000-1005.

Datti, A., Beccari, T., Emiliani, C., Stirling, J. L. \& Orlacchio, A. (1993) Blood testoterone levels are correlated with b-N-actylhexosaminidase activity in human caput epididymis. Biochem Mol Biol Int, 30, 1013-1020.

Diekman, A. B., Norton, E. J., Westbrook, V. A., Klotz, K. L., NaabyHansen, S. \& Herr, J. C. (2000) Anti-sperm antibodies from infertile patients and their cognate sperm antigens: a review. Identity between SAGA-1, the H6-3C4 antigen, and CD52. Am J Reprod Immunol, 43, 134-43.

Diekman, A. B., Westvrook-Cae, V. A., Naaby- Hansen, S., Klotz, K. L., Flickinger, C. J. \& Herr, J. C. (1997) Biochemical characterisation of sperm agglutination antigen-1, a human sperm surface antigen implicated in gamete interactions. Biol Reprod, 57, 1136-1144.

Elisen, M. G., van Kooij, R. J., Nolte, M. A., Marquart, J. A., Lock, T. M., Bouma, B. N. \& Meijers, J. C. (1998) Protein C inhibitor may modulate human sperm-oocyte interactions. Biol Reprod, 58, 670-7.

Fenichel, P., Cervoni, F., Hofman, P., Deckert, M., Emiliozzi, C., Hsi, B. L. \& Rossi, B. (1994) Expression of the complement regulatory protein CD59 on human spermatozoa: characterization and role in gametic interaction. Mol Reprod Develop, 38, 338-346.

Focarelli, R., Francavilla, S., Francavilla, F., Giovampaola, D. C., Santucci, A. \& Rosati, F. (1999) gp20, a sialylglycoprotein of the human capacitated sperm surface is the homologue of the leukocyte CD52 antigen: analysis of the effect of anti-CD52 monoclonal antibody (CAMPATH-1) on capacitated sperm. Mol Human Reprod, 5, 46-51.

Focarelli, R., Giovampaola, C. D., Seraglia, R., Brettoni, C., Sabatini,
L., Pescaglini, M. \& Rosati, F. (1999) Biochemical and MALDI analysis of the human sperm antigen gp20, homologue of leukocyte CD52. Biochem Biophys Res Commun, 258, 639-643.

Focarelli, R., Giuffrida, A., Capparelli, S., Scibona, M., MenchinisFabris, F., Francavilla, F., Francavilla, S., Della Giovampaola, C. \& Rosati, F. (1998) Specific localization in the equatorial segment of gp20, a $20 \mathrm{kDa}$ sialylglycoprotein of the capcacitated human spermatozoon acquired during epididymal transit which is necessary to penetrate zona-free hamster eggs. Mol Human Reprod, 4, 119-125.

Hale, G., Rye, P. D., Warford, A., Lauder, I. \& Brito-Babapulle, A. (1993) The glycosylphosphatidylinositol-anchored lymphocyte antigen CDw52 is associated with the epididymal maturation of human spermatozoa. J Reprod Immunol, 23, 189-205.

Hammani-Hamza, S., Doussau, M., Bernard, J., Rogier, E., Duquenne, C., Richard, Y., Lefèvre, A., Finaz, C. M. \& Bernard, J. (2001) Cloning and sequencing of SOB3, a human gene coding for a sperm protein homologous to an antimicrobial protein and potentially involved in zona pellucida binding. Mol Human Reprod, 7, 625 632.

Hayashi, M., Fujimoto, S., Takano, H., Ushika, T., Abe, K., Ishikura, H., Yoshida, M. C., Kirchhoff, C., Ishibashi, T. \& Kasahara, M. (1996) Characterization of a human glycoprotein with a potential role in sperm-egg fusion: cDNA cloning, immunohistochemical localization, and chromosomal assignment of the gene AEGL1). Genomics, 32, 367-374.

Hutter, H., Hammer, A., Blaschitz, A., Hartmann, M., Mahnert, W., Sedlmayr, P., Primus, G., Rosenkranz, C., Gebru, G., Henkel, R. \& Dohr, G. (1996) The monoclonal antibody GZS-1 detects a maturation-associated antigen of human spermatozoa that is also present on the surface of human mononuclear blood cells. J Reprod Immunol, 30, 115-32.

Isojima, S., Tsuji, Y., Kameda, K., Shigeta, M., Hakamori, S.-I. (1990): Coating antigens of human seminal plasma involved in fertilization. In: Gamete Interactions: Prospects for Immunocontraception, Alexander, N. J., Griffin, D., Spieler, J. M. D., Waites, G. M. H. (eds.), New York: Wiley-Liss, pp 155-174.

*Jury, J. A. \& Frayne, J. H. L. (1998) Sequence analysis of a variety of primate fertilin a genes: evidence for non-functional genes in the gorilla and man. Mol Reprod Develop, 51, 92-97.

*Jury, J. A., Frayne, J. \& Hall, L. (1997) The human fertilin a gene is non-functional: implications for its proposed role in fertililization. Biochem J, 321, 577-581.

Kameda, K., Takada, Y., Hasegawa, A., Tsuji, Y., Koyama, K. \& Isojima, S. (1991) Sperm immobilizing and fertilization-blocking monoclonal antibody $2 \mathrm{C} 6$ to human seminal plasma and characterization of the antigen epitope corresponding to the monoclonal antibody. J Reprod Immunol, 20, 27-41.

Kameda, K., Tsuji, Y., Koyoma, K. \& Isojima, S. (1992) Comparative studies of the antigens recognised by sperm-immobilising monoclonal antibodies. Biol Reprod, 46, 349-357.

Kirchhoff, C., Habben, I., Ivell, R \& Krull, N. (1991) A major human epididymis-specific cDNA encodes a protein with sequence homology to extracellular proteinase inhibitors. Biol Reprod, 45, 350-357.

Kirchhoff, C., Krull, N., Pera, I. \& Ivell, R. (1993) A major mRNA of the human epididymis principal cells, HE5, encodes the leucocyte differentiation CDw52 antigen peptide backbone. Mol Reprod Develop, 34, :8-15.

Kirchhoff, C., Osterhoff, C. \& Young, L. (1996) Molecular cloning and characterization of HE1, a major secretory protein of the human 
epididymis. Biol Reprod, 54, :847-856.

Kirchhoff, C. (1994) A major messenger ribonucleic acid of the rodent epididymis encodes a small glycosylphosphatidylinositolanchored lymphocyte surface antigen. Biol Reprod, 50, 896-902.

Kirchhoff, C. (1996) CD52 is the 'major maturation-associated' sperm membrane antigen. Mol Human Reprod, 2, 9-17.

Kirchhoff, C. (1998) Molecular characterization of epididymal proteins. Reviews of Reproduction, 3, 86-95.

Kirchhoff, C., Pera, L., Rust, W. \& Ivell, R. (1994) Major human epididymis-specific gene product, HE3, is the first representative of a novel gene family. Mol Reprod Develop, 37, 130-137.

Krätzschmar, J., Haendler, B., Eberspaecher, U., Roosterman, D., Donner, P. \& Schleuning, W.-D. (1996) The human cysteine-rich secretory protein (CRISP) family. Primary structure and tiissue distribution of CRISP-1, CRISP-2 and CRISP-3. Eur J Biochem, 236, 827836.

Krull, N., Ivell, R., Osterhoff, C. \& Kirchhoff, C. (1993) Region-specific variation of gene expression in the human epididymis as revealed by in situ hybridization with tissue-specific cDNAs. Mol Reprod Develop, 34, 16-24.

Larsen, L. B., Rovn, P., Boisen, A., Berglund, L. \& Petersen, T. E. (1997) Primary structure of EPV20, a secretory glycoprotein continaing a previously uncharacteriszed type of domain. Eur J Biochem, $243,437-441$.

Laurell, M., Christensson, A., Abrahamson, P.-A., Stenflo, J. \& Lilja, H. (1992) Protein C inhibitor in human body fluids. Seminal plasma is rich in inhibitor antigen deriving from cells throughout the male reproductive system. J Clin Invest, 89, 1094-1101.

Lefèvre, A., Duquenne, C., Rousseau-Merck, M. F., Rogier, E. \& Finaz, C. (1999) Cloning and characterization of SOB1, a new testisspecific cDNA encoding a human sperm protein probably involved in oocyte recognition. Biochem Biophys Res Commun, 259, 60-6.

Lefèvre, A., Ruis, C. M., Chokomian, S., Duquenne, C. \& Finaz, C. (1997) Characterization and isolation of SOB2, a human sperm protein with a potential role in oocyte membrane binding. Mol Human Reprod, 3, 507-516.

Legare, C., Gaudreault, C., St-Jacques, S. \& Sullivan, R. (1999) $\mathrm{P} 34 \mathrm{H}$ sperm protein is preferentially expressed by the human corpus epididymidis. Endocrinology, 140, 3318-3327.

Lin, Y. C., Sun, G. H., Lee, Y. M., Guo, Y. W. \& Liu, H. W. (2001) Cloning and Characterization of a Complementary DNA Encoding a Human Epididymis-Associated Disintegrin and Metalloprotease 7 Protein. Biol Reprod, 65, 944-950.

*Lin, Y., Kimmel, L. H., Myles, D. G. \& Primakoff, P. (1993) Molecular cloning of the human and monkey sperm surface protein PH-20. Proc Nat Acad Sci US, 90, 10071-10075.

Liu, H. W., Liu, Y. C., Chao, C. F., Chang, S. Y. \& Sun, G. H. (2000) GP-83 and GP-39, two glycoproteins secreted by human epididymis and conjugated to spermatozoa during maturation. Mol Human Reprod, 6, 422-428.

Liu, Q., Hamil, K. G., Sivashanmugam, P., Grossman, G., Soundararajan, R., Rao, A. J., Richardson, R. T., Zhang, Y. L., O'Rand, M. G., Petrusz, P., French, F. S. \& Hall, S. H. (2001) Primate epididymis-specific proteins: characterization of ESC42, a novel protein containing a trefoil-like motif in monkey and human. Endocrinology, 142, 4529-39.

Mahony, M. C. \& Alexander, N. J. (1991) Sites of antisperm antibody action. Hum Reprod, 6, 1426-30.

Malm, J., Sorensen, O., Persson, T., Frohm-Nilsson, M., Johansson, B., Bjartell, A., Lilja, H., Stahle-Backdahl, M., Borregaard, N. \& Egesten, A. (2000) The human cationic antimicrobial protein (hCAP-
18) is expressed in the epithelium of human epididymis, is present in seminal plasma at high concentrations, and is attached to spermatozoa. Infect Immun, 68, 4297-302.

Miranda, P. V. \& Tezon, J. G. (1992) Characterization of fibronectin as a marker for human epididymal sperm maturation. Mol Reprod Develop, 33, 443-450.

Martinez-Ruiz, C. M., Duquenne, C., Treton, D., Lefèvre, A. \& Finaz, C. (1998) SOB3, a human sperm protein involved in zona pellucida binding: physiological and biochemical analysis, purification. Mol Reprod Develop, 49, 286-297.

Moore, A., Penfold, L. M., Johnson, J. L. \& Latchman, D. S. (1993) Human sperm-egg binding is inhibited by peptides corresponding to core region of an acrosomal serine protease inhibitor. Mol Reprod Develop, 34, 280-291.

Naz, R. Q., Morte, C., Garcia-Framus, V., Kaplan, P. \& Martinez, P. (1993) Characterization of a sperm-specific monoclonal antibody and isolatio of 95-kilodalton fertilization antigen-2 from human sperm. Biol Reprod, 49, 1236-1244.

O'Bryan, M. K., Mallidas, C., Murphy, B. F. \& Baker, H. W. G. (1994) Immunohistological localization of clusterin in the male genital tract in humans and marmosets. Biol Reprod, 50, 502-509.

O'Bryan, M. K., Murphy, B. F., Liu, D. Y., Clarke, G. N. \& Baker, H. W. G. (1994) The use of anticlusterin monoclonal antibodies for the combined assessment of human sperm morphology and acrosome integrity. Human Reprod, 9, 1490-1496.

Osterhoff, C., Ivell, R. \& Kirchhoff, C. (1997) Cloning of a human epididymis-specific mRNA, HE6, encoding a novel member of the seven transmembrane-domain receptor superfamily. DNA and Cell Biol, 16, 379-389.

Osterhoff, C., Kirchhoff, C., Krull, N. \& Ivell, R. (1994) Molecular cloning and characteriztation of a novel human sperm antigen (HE2) specifically expressed in the proximal epididymis. Biol Reprod, 50, 516-525.

Osterhoff, C., Lassalle, B., Finaz, C., Ivell, R. \& Kirchhoff, C. (1993) A secretory protein of the human epididymis appears to be involved in the gamete recognition process. J Reprod Fertil, Abstract Series 12, C31, 21.

Paju, A., Bjartell, A., Zhang, W. M., Nordling, S., Borgstrom, A., Hansson, J., \& Stenman, U. H. (2000) Expression and characterization of trypsinogen produced in the human male genital tract. Am J Pathol. 157, 2011-21.

Patrizio, P. \& Salameh, W. A. (1998) Expression of the cystic fibrosis transmembrane conductance regulator (CFTR) mRNA in normal and pathological adult human epididymis. J Reprod Fertil, Supplement 53, 261-270.

Raczek, S., Yeung, C. H., Hasilik, A., Robenek, R., Hertle, L., Schulze, H \& Cooper, T. G. (1995) Immunocytochemical localisation of some lysosomal hydrolases, their presence in luminal fluid and their directional secretion by human epididymal cells in culture. Cell Tiss Res, 280, 415-426.

Richardson, R. T., Sivashanmugam, P., Hall, S. H., Hamil, K. G., Moore, P. A., Ruben, S. M., French, F. S. \& O'Rand, M.(2001) Cloning and sequencing of human Eppin: a novel family of protease inhibitors expressed in the epididymis and testis. Gene. 270, 93-102. Ross, P., Vigneault, N., Provencher, S., Potier, M. \& Roberts, K. D. (1993) Partial characterization of galactosyltransferase in human seminal plasma and its distribution in the human epididymis. $\mathrm{J}$ Reprod Fertil, 98, 129-137.

Saalmann A, Munz S, Ellerbcrock K, Ivell R, Kirchhoff C. Novel sperm-binding proteins of epididymal origin contain four fibronectinpe-II modules. Mol Reprod Develop, 2001;58:88-100. 
modèSanjurjo, C., Dawidowsky, A. R., Cameo, M. S., Gonzalez Echeverria, F. \& Blaquier, J. A. (1990) Participation of human epididymal sperm coating antigens in fertilization. $J$ Androl, 11, 476-483.

Schaller, J., Glander, H. J. \& Dethloff, J. (1993) Evidence of B1 integrins and fibronectin on spermatogenic cells in human testis. Human Reprod, 8, 1873-1878.

Simpson, K. L. \& Holmes, C. H. (1994) Presence of the complementregulatory protein membrane cofactor protein $(\mathrm{MCP}, \mathrm{CD} 46)$ as a membrane-associated product in seminal plasma. J Reprod Fertil, $102,419-424$.

Sun, G. H., Ln, Y. C., Guo, Y. W., Chang, S. \& Liu, H. W. (2000a) Purification of GP-83, a glycoprotein secreted by the human epididymis and conjugated tio mature spermatozoa. Mol Human Reprod, 6, 429-444.

Sun, G. H., Liu, H. W., Lin, Y. C., Yu, D. S. \& Chang, S. Y. (2000b) Identification of maturation-related wheat-germ lectin-binding proteins in the culture of human corpus epididymal epithelial cells. Arch Androl, 45, 53-60.

Tesarik, J., Drahorad, J. \& Peknicova, J. (1988) Subcellular immunochemical localization of acrosin in human spermatozoa during the acrosome reaction and zona pellucida penetration. Fertil Steril, 50, 133-141.

Tezon, J. G., Ramella, E., Cameo, M. S., Vazquez, M. H. \& Blaquier, J. A. (1985) Immunocytochemical localization of secretion antigens in the human epididymis and their association with spermatozoa. Biol Reprod, 32, 591-597.

Tokugawa, Y., Kunishige, I., Kubota, Y., Shimoya, K., Nobunaga, T., Kimura, T., Saji, F., Murata, Y., Eguchi, N., Oda, H., Urade, Y. \& Hayaishi, O. (1998)

Lipocalin-type prostaglandin S synthase in human male reproduticve organs and seminal plasma. Biol Reprod, 58, 600-607.

Wong, P. Y. D., Huang, S. J., Leung, A. Y. H., Fu, W. O., Chung, Y. W., Zhou, T. S., Yip, W. W. K. \& Chan, W. K. L. (1992) Physiology and pathophysiology of electrolyte transport in the epididymis. In: Spermatogenesis, Fertilization, Contraception. Molecular, Cellular and Endocrine Events in Male Reproduction. Nieschlag, E., Habenicht, U.-F. (eds), Schering Foundation Symposium, SpringerVerlag, Berlin. Pp. 319-344.

Yan, Y. C., Mitsudo, S. M., Wang, L. F. \& Koide, S. S. (1984) Immunolocalization of a sperm membrane protein in human male reproductive organs. Fertil Steril, 42, 614-617.

Yeung, C. H., Cooper, T. G. \& Senge, T. (1990) Histochemical localization and quantification of a-glucosidase in the epididymis of men and laboratory animals. Biol Reprod, 42, 669-676.

Yeung, C.-H., Schröter, S., Wagenfeld, A., Kirchhoff, C., Kliesch, S., Poser, D., Weinbauer, G. F., Nieschlag, E. \& Cooper, T. G. (1997) Interaction of the human epididymal protein CD52 (HE5) with epididymal spermatozoa from men and cynomolgus monkeys. Mol Reprod Develop, 48, 267-275.

Zhu, X. \& Naz, R. K. (1997) Fertilization antigen-1: cDNA cloning, testis-specific expression, and immunocontraceptive effects. Proc Nat Acad Sci US, 29, 4704-4709. le représenté par l'ovocyte de hamster dépellucidé, qui est éthiquement acceptable, les spermatozoïdes épididymaires capacités révèlent une capacité croissante à pénétrer les œufs (Fig. 1g) Ces résultats peuvent être expliqués en partie par la proportion croissante de spermatozoïdes RA (+) dans la population mature, mais il existe toujours une différence évidente dans la réponse des spermatozoïdes du corps et de la queue, alors qu'ils peuvent tous effectuer la RA.

Comme noté plus haut (cf « $4 »$ ), les sécrétions épididymaires peuvent être impliquées en modulant la fluidité de la membrane plasmique.

\section{Condensation chromatinienne}

La condensation de la chromatine qui s'effectue durant la maturation épididymaire a été monitorée indirectement par l'exclusion des colorants qui se lient aux nucléoprotéines (le bleu d'aniline se lie aux histones restants), ou à l'ADN lui-même (l'acridine orange montre une fluorescence rouge avec l'ADN simple brin, et verte avec l'ADN bicaténaire). Avec les 2 méthodes on observe une décroissance dans l'accessibilité du colorant, qui est interprétée comme un accroissement progressif de la condensation chromatinienne (Fig. 1h).

Celle-ci reflète l'oxydation des groupes sulfydryl des protamines [3] mais on ne sait rien des enzymes impliquées chez l'homme.

\section{Capacité à féconder in vivo et in vitro}

Pour des raisons d'ordre éthique, les seules études concernant le pouvoir fécondant des spermatozoïdes d'origine épididymaire, portent sur des hommes infertiles. Dans ces études une épididymo-vasostomie est réalisée chez des hommes azoospermiques en raison d'une obstruction épididymaire. Le site d'anastomose se situe en amont de la région d'occlusion, aussi différentes portions de l'épididyme sont court-circuitées. On observe que plus la longueur du canal épididymaire restant est importante, plus le taux de grossesse est élevé (Fig. 1i). Les techniques d'assistance médicale à la procréation (AMP) ont permis d'obtenir des grossesses par FIV, à partir de spermatozoïdes recueillis dans différentes régions d'un épididyme obstrué. Il a été démontré que les taux de fécondation et de grossesses sont d'autant plus élevés que la longueur de l'épididyme dans lequel les spermatozoïdes ont transité, est grande (Fig.1j). Plus ce passage épididymaire est long, plus grandes sont les chances d'interaction avec les sécrétions épididymaires. 


\section{PROTÉINES ÉPIDIDYMAIRES IMPLIQUÉES DANS LA MATURATION DES SPERMATOZOÏDES.}

Plusieurs techniques ont été appliquées pour étudier les protéines épididymaires susceptibles d'être impliquées dans la maturation et le stockage des spermatozoïdes. Les premiers travaux sur les protéines impliquaient la fabrication d'anticorps polyclonaux ou monoclonaux dirigés : (i) contre les spermatozoïdes humains éjaculés [2, 4], parce que des protéines de revêtement pouvaient adhérer à ces spermatozoïdes éjaculés; (ii) contre des protéines éluées à partir de la surface membranaire des spermatozoïdes éjaculés [48], parce que ces protéines peuvent permettre la fixation à la zone pellucide [29] ; (iii) contre des protéines du plasma séminal [31], parce que des protéines sécrétées par l'épididyme et fixées sur les spermatozoïdes sont retrouvées dans le liquide séminal. Des anticorps dirigés contre certaines protéines venant d'autres organes humains (comme la fibronectine ou la clusterine), ont été utilisés, et les activités enzymatiques ont été mesurées dans les homogénats [43], ou par histochimie [49].

Plus récemment, les techniques de biologie moléculaire, comme le clonage à partir du screening de sondes gènesspécifiques et de banques différentielles, ont été appliquées à l'épididyme [33], et ont révélé des transcrits de gènes exprimés spécifiquement dans l'épididyme. Les données concernant des séquences d'oligo-nucléotides, et la composition en acides aminés des protéines traduites, ont révélé de surprenantes similitudes entre des protéines impliquées dans différentes fonctions. La séquence nucléotidique codant pour une protéine impliquée dans la liaison à la ZP $(\mathrm{P} 34 \mathrm{H})$, identifie celle-ci comme appartenant à la famille "déshydrogénase/réductase ». Une autre protéine impliquée dans la liaison à la $\mathrm{ZP}, \mathrm{SOB} 3$ [24], a une séquence identique à celle d'une protéine cationique anti-microbienne originaire de l'épididyme humain : hCAP-18 [37].

Sur ce point, une certaine confusion a été introduite par Agerberth et al., [1], qui ont identifié le gène hCAP-18 dans le testicule humain. En fait, les auteurs ont utilisé des filtres commerciaux pré-chargés avec des ARNm provenant d'organes humains variés. On sait que de tels échantillons contiennent souvent des ARNm provenant de "contenu scrotal total ", et renferment donc en plus du tissu épididymaire (vérifié par la présence d'une sécrétion HES d'origine purement épididymaire dans le champ "testiculaire 》 d'un tel essai). Dans le cas de hCAP-18/SOB3, les anticorps ne détectent pas la protéine dans le testicule, ce qui en fait une authentique sécrétion épididymaire.

Un antigène majeur de maturation de l'épididyme humain (CD52) a été découvert par différents groupes, avec des appellations variées : H6-3C4 [32], HE5 [34], GZS-1 [28] SAGA-1 [11], S19 [36], et gp20 [17, 18] (Pour synthèse : voir [12]).
Le tableau 1 donne la liste des protéines identifiées jusqu'à présent en tant que sécrétions de l'épididyme humain, qui peuvent être impliquées dans l'acquisition du pouvoir fécondant des spermatozoïdes épididymaires. Leurs noms, pseudonymes, poids moléculaires, PI, leurs fonctions prouvées ou suspectées, sont précisés. Sont également présentés le site d'expression du gène, la localisation de la protéine au sein de l'organe, mais aussi le niveau où la protéine apparaît sur les spermatozoïdes transitant dans l'épididyme, et enfin le site de localisation de l'antigène au niveau du spermatozoïde.

\section{Protéines d'origine exclusivement testiculaire}

Les protéines testiculaires impliquées dans les interactions gamétiques sont aussi listées pour être complet. Ce sont des constituants inhérents des spermatozoïdes avant qu'ils ne quittent le testicule, et qui sont supposés impliqués dans la liaison à la ZP et dans la fusion avec l'ovocyte.

\section{Protéines testiculaires et épididymaires}

D'autres protéines sont exprimées à la fois dans le testicule et l'épididyme. Les régions épididymaires listées sont celles décrites dans les papiers cités, bien que chez l'homme la tête épididymaire contient à la fois un canal épididymaire commun et de nombreux canaux efférents [50]. Dans cette région, la clustérine se lie à des lipides qui sont exposés à la surface des spermatozoïdes morts. Parmi les protéines des canaux efférents et qui sont également sécrétées, de manière plus distale, dans le corps épididymaire, l'une est un inhibiteur de protéines (Eppin) et trois (SOB1, ARP, et fibronectine), sont impliquées dans la fusion avec l'ovocyte. On peut déduire ce rôle des mauvais résultats du « hamster-test » pratiqué avec des spermatozoïdes incubés avec des anticorps dirigés contre la protéine en question, alors que la lésion à la ZP, la mobilité, ainsi que la RA, ne sont pas affectés par l'anticorps. L'encombrement stérique de l'anticorps, débordant sur un site adjacent connu pour être impliqué dans la liaison, constitue un problème, et parfois de plus petits fragments Fab doivent être utilisés. Une localisation sur la région équatoriale de l'acrosome (région de contact inter-gamétique), est compatible avec une implication dans la fonction fusiogène. Ce n'est cependant pas toujours le cas, et on connaît une protéine de surface éluée par des forces ioniques élevées, qui est localisée par dessus la région équatoriale [48], aussi les anticorps dirigés contre elle empêchent la fusion mais pas la liaison à la ZP [44]. Cela peut-être dû à une relocalisation de la protéine sur le segment équatorial au cours de la capacitation, ce qui est le cas pour gp20/CD52 [16].

La localisation dans l'épididyme de plusieurs protéines également présentes dans le testicule (PDGS, qui est une lipocaïne), n'est pas déterminée avec précision. Dans la plupart des cas on peut présumer, voire affirmer à partir de coupes histologiques, que c'est le corps de l'épididyme qui a été 
examiné ; toutefois, celà n'implique pas nécessairement que la protéine est absente des autres régions, puisqu'elles peuvent ne pas avoir été examinées, ou elles peuvent ne pas être présentes (comme c'est le cas de BCAVD : He et al., [27]. L'expression de la serpine (impliquée dans la fusion et dans la liaison à la ZP) et du trypsinogène (précurseur de la forme active impliquée dans la liaison à la zona) est aussi détectée en position plus distale, dans la queue de l'épididyme.

\section{Protéines d'origine exclusivement épididymaire}

Comme pour les protéines mentionnées plus haut, certaines sont exprimées exclusivement dans la tête (cônes efférents ou canal), et tout au long du canal épididymaire HE6 (considéré comme un transporteur épithélial), est localisé uniquement dans la tête, mais les observateurs d'une expression céphalique des protéines $\mathrm{C}$ et $\mathrm{S}$, protéases impliquées dans le processus d'immuno-suppression, peuvent correspondre au fait que seul du tissu issu de patients porteurs d'agénésie vésiculo-déférentielle a été examiné, alors qu'il n'existe pas de tissu plus distal, de sorte que ces protéines peuvent être présentes dans des régions distales d'épididymes normaux.

Des protéines impliquées dans la liaison à la $\mathrm{ZP}$ (antigène $3 \mathrm{~B} 2 \mathrm{~F}$ ), et la fusion gamétique (SOB2), sont trouvées tout au long de l'épididyme, mais une gradation régionale de l'expression et de l'activité d'autres protéines épididymaires paraît évidente. Les activités des enzymes NAG $\beta$-glucosidase et $\beta$ galactosidase sont plus élevées dans les cônes efférents que dans les régions plus distales de l'épididyme et le canal déférent. L'expression d'HE2 (impliqué dans la fusion, et ayant une activité anti-microbienne), et l'activité galactosyl transférase, sont aussi plus élevées dans la région de la tête. D'autre part, l' $\alpha$ fucosidase, l' $\alpha$ mannosidase, et la $\beta$ glucoronidase, sont plus actives dans l'épididyme que dans les canaux efférents ou le déférent. De manière similaire l'expression de P34H (fixation à la ZP) est plus élevée dans le corps que dans la tête et la queue épididymaires. Pour HE1 (protéine liant les stérols), et HE3 nouvellement décrite, une expression biphasique est présente, plus élevée dans le déférent que dans la queue. Pour des substances qui sont libérées dans la lumière, la signification d'une expression localisée dans le corps n'est pas claire, puisque ces substances vont transiter avec les spermatozoïdes et se mélangeront avec eux. En fait, pour les sécrétions de $\mathrm{P} 34 \mathrm{H}$ [5], et HE5/CD52 [53], il y a de plus grandes quantités de protéines sur les spermatozoïdes de la queue que sur ceux du corps, en dépit d'une expression génique plus faible dans la queue.

Néanmoins, des protéines exprimées tout le long du canal, mais en plus grandes quantités dans les régions les plus distales, fourniraient plus de sécrétions par spermatozoïde que d'autres, et pourraient être impliquées dans le stockage des spermatozoïdes dans la queue.
Une protéine de revêtement impliquée dans la fusion avec l'ovocyte, l' $\alpha$ glucosidase, et la protéine anti-microbienne hCAP-18, présentent toutes de tels gradients de sécrétion. D'autres protéines sont trouvées limitées dans le corps et la queue (les protéases GP-83 et GP-39 impliquées dans la fusion), ou seulement dans la queue (HE4-HE12), ces dernières censées être des facteurs décapacitants qui maintiennent les spermatozoïdes dans un état quiescent jusqu'à l'éjaculation.

\section{Interaction des protéines avec les spermatozoïdes}

Les protéines épididymaires qui adhèrent élecrostatiquement à la surface des spermatozoïdes peuvent être éluées dans un milieu de force ionique élevée, et incluent une protéine de surface [44], ainsi que l'ARP [35]. La première a été impliquée dans la fusion inter-gamétique, car des anticorps dirigés contre elles bloquent la pénétration des spermatozoïdes dans les ovocytes de hamster dépellucidés. En revanche, l'ARP est éluée facilement de la surface cellulaire, et n'est pas considérée comme participant au processus de fusion comme le fait la protéine $\mathrm{D} / \mathrm{E}$ [AEG], son équivalent chez le rat [42]. Cependant, des études récentes indiquent que des molécules protéiques ARP restent sur la région équatoriale après extraction saline, et que des anticorps contre ARP bloquent la pénétration des spermatozoïdes [6]. Par analogie avec l'épididyme de rat (sur lequel on a plus de connaissances), il est possible que la force ionique du milieu épididymaire soit faible, à causes de fortes concentrations de solutés organiques non chargés, ce qui maintiendrait ces protéines sur le spermatozoïde [8].

$\mathrm{Au}$ moins 2 sécrétions épididymaires (CD52 et P34H) adhèrent à la membrane du spermatozoïde par des ancrages glycérophosphoinnositol (GP). La protéine est ainsi ancrée à la membrane de la cellule épididymaire qui libère des vésicules (pouvant être appelées « épididymosomes ») dans la lumière. Dans tous les cas, le transfert aux spermatozoïdes est médié par de telles vésicules [21, 53]. La protéine $\mathrm{P} 34 \mathrm{H}$ reste sur la tête spermatique jusqu'à la RA, jusqu'à ce que son rôle dans la fixation à la ZP soit achevé [5].

\section{CONCLUSION - RESUME}

En plus des protéines qui sont sur les spermatozoïdes au moment où ils entrent dans le canal épididymaire, des protéines sont ajoutées, qui sont parfois les mêmes que celles du testicule (différentes isoformes dans le cas de la clustérine), mais qui sont le plus souvent de nature différente, constituant ainsi des protéines épididymaires spécifiques. Au cours de leur progression dans l'épididyme, les spermatozoïdes rencontrent un environnement varié et variable, en rapport avec les protéines avec lesquels ils rentrent en contact. Dans l'épididyme proximal les spermatozoïdes sont soumis à l'action de certaines enzymes et exposés à des protéines impliquées 


\section{Clusterin}

\section{SOB1}

Eppin

HE2

\section{FN}

\section{P34H}

\section{HE1}

\section{HE3}

\section{gp20}

\section{ARP}

\section{SOB2}

hCAP1/SOB3

Figure 2 : Représentation schématique de la localisation des gènes exprimant les protéines épididymaires sécrétées (les régions épididymaires sont approximatives) (pour les abréviations, cf. légendes du tableau 1). 
dans les modifications membranaires et la fusion gamétique. Dans la partie moyenne de l'organe, un autre groupe d'enzymes devient actif ; les protéines prédominantes sont associées avec des transports de stérols (HE1), susceptibles de modifier la membrane pour permettre l'incorporation de la protéine de liaison à la zona : P34H, ancrée au GPI. Dans la région plus distale les spermatozoïdes rencontrent des concentrations croissantes de glucosidase et de protéase (protéines impliquées à la fois dans la liaison à la ZP et la fusion ovocytaire), de l'antigène majeur de maturation $\mathrm{CD52}$, de protéines à activité anti-microbienne, et enfin de facteurs de décapacitation, qui les aident à survivre avant l'éjaculation. En dépit des difficultés à préciser les régions épididymaires correspondant aux détections des ARNm et des protéines citées, et des discordances entre des études concernant la même protéine, la figure 2 tente de dresser un vaste tableau des variations régionales dans la localisation des protéines épithéliales. Les spermatozoïdes vont rentrer en contact avec ces sécrétions, au niveau du site d'excrétion, et dans les régions plus distales.

L'adhérence des protéines à différents domaines (membrane plasmique recouvrant l'acrosome ou segment équatorial), dépend de la nature de la protéine, de la composition lipidique locale de la membrane concernée, et de l'environnement (ionique en particulier), dans lequel le spermatozoïde se trouve. La localisation éventuelle sur un spermatozoïde capacité (membrane acrosomale), ou sur un spermatozoïde ayant effectué la RA (région équatoriale), va ainsi orienter leur rôle, soit dans la liaison à la ZP (P34H), soit dans la fusion avec l'ovocyte (gp20) (Fig. 3). A la fois les protéines et les membranes spermatiques peuvent être modifiées durant le transit épididymaire, par la succession des activités enzymatiques auxquelles les spermatozoïdes sont soumis dans les différentes régions épididymaires (par exemple : les glycosyl transférases, les glycosidases et les protéases), et qui peuvent ajouter ou retirer des carbohydrates ou des peptides de la surface du spermatozoide. Les activités protéasiques sont à leur tour modifiées par des inhibiteurs de protéases libérés de l'épithélium et attachés aux spermatozoïdes.

\section{Remerciements}

Les travaux personnels cités dans cette revue ont été soutenus en grande partie par la « Deutsche Forschungsgemeinnschaft ».

\begin{tabular}{l} 
Testicule: \\
\hline 1 FA-1 \\
2 PH-20 \\
3 SP-40,40 \\
4 Acrosine \\
Tête: \\
\hline 5 SP-40,40 \\
6 SOB1 \\
Corps: \\
7 P34H \\
8 gp20 \\
9 Fibronectine \\
10 GP-83 \\
11 GP-39 \\
Queue: \\
12 SCP \\
13 Serpine \\
14 SOB3 \\
15 Serpine \\
Toutes régions: \\
16 SOB2 \\
17 ARP
\end{tabular}

Figure 3 : Représentation schématique (pas à l'échelle) de la localisation des protéines intrinsèques (d'origine testiculaire) et extrinsèques (sécrétées, d'origine épididymaire), sur les différents domaines membranaires de la tête du spermatozoïde humain, en relation avec les différentes étapes du processus de fécondation. 


\section{RÉFÉRENCES}

1. AGERBERTH B., GUNNE H., ODEBERG J., KOGNER P., BOMAN H.G., GUDMUNDSSON G.H. : FALL-39, a putative human peptide antibiotic, is cysteine-free and expressed in bone marrow and testis. Proc. Nat. Acad. Sci. US., 1995, 92 : 195-199.

2. BATOVA I., KAMEDA K., HASEGAWA A., KOYAMA K., TSUJI Y., ISOJIMA S. : Monoclonal antibody recognising an apparent peptide epitope of human seminal plasma glycoprotein and exhibiting sperm immobilizing activity. J. Reprod. Immunol., 1990, $17:$ 1-6.

3. BEDFORD J.M., CALVIN H., COOPER G.W. : The maturation of spermatozoa in the human epididymis. J. Reprod. Fertil., 1973, Suppl $18: 199-213$.

4. BOUÉ F., LASSALLE B., DUQUENNE C.et al. : Human sperm proteins from testicular and epididymal origin that participate in fertilization: modulation of sperm binding to zona-free hamster oocytes, using monoclonal antibodies. Mol. Reprod. Develop., $1992,33: 470-480$.

5 . BOUÉ F., BERUBÉ B., DE LAMIRANDE E., GAGNON C., SULLIVAN R. : Human sperm-zona pellucida interaction is inhibited by an antiserum against a hamster sperm protein. Biol. Reprod., 1994, 51 : 577-587.

6. COHEN D.J., ELLERMAN D.A., BUSSO D. et al. : Evidence that human epididymal protein ARP plays a role in gamete fusion through complementary sites on the surface of the human egg. Biol. Reprod., 2001, 65 : 1000-1005.

7. COOPER T.G. : Apologie de la fonction de l'épididyme dans l'espèce humaine. Contracept. Fertil. Sex., 1992, 20 : 363-373.

8. COOPER T.G. : Interactions between epididymal secretions and spermatozoa.. J. Reprod. Fertil., 1998, Suppl 53 : 119-136.

9. COOPER T.G., RACZEK S., YEUNG C.H., SCHWAB E., SCHULZE H., HERTLE L. : Composition of fluids obtained from human epididymal cysts. Urol. Res, 1992, $20: 275-280$.

10. DELPECH S., LECOMTE P., LECOMTE C. : Étude in vitro chez l'homme de la liason des spermatozoïdes épididymaires à la zone pellucide. J. Gynecol. Obstet. Biol. Reprod., 1988, 17 : 339-342.

11. DIEKMAN A.B., WESTBROOK-CASE V.A., NAABYHANSEN S., KLOTZ K.L., FLICKINGER C.J., HERR J.C. : Biochemical characterization of sperm agglutination antigen-1, a human sperm surface antigen implicated in gamete interactions. Biol. Reprod., 1997, 57 : 1136-1144.

12. DIEKMAN A.B., NORTON E.J., WESTBROOK V.A., KLOTZ K.L., NAABY-HANSEN S., HERR J.C. : Anti-sperm antibodies from infertile patients and their cognate sperm antigens: a review. Identity between SAGA-1, the H6-3C4 antigen, and CD52. Am. J. Reprod. Immunol., 2000, 43 : 134-43.

13. EDIRISINGHER W.R., JUNK S.M., MATSON P.L., YOVICH J.L. : Changes in motility patterns by in-vitro culture of fresh and frozen/thawed testicular and epididymal spermatozoa: implication for planning treatment by intracytoplasmic sperm injection. Human Reprod., 1996, $11:$ 2474-2476.

14. FINAZ C., LEFÈVRE A. : Gamete recognition in mammals: sperm and zona pellucida interactions. Contracept. Fertil. Sex., 1998, 26, 542-548.

15. FINAZ C., MARTIN-RUIZ C., LEFÈVRE A. : Interaction des gamètes et protéines de reconnaissance. Médicine/Sciences, $1998,14: 175-182$.
16. FOCARELLI R., GIUFFRIDA A., CAPPARELLI S. et al. : Specific localization in the equatorial segment of gp 20 , a $20 \mathrm{kDa}$ sialylglycoprotein of the capacitated human spermatozoon acquired during epididymal transit which is necessary to penetrate zona-free hamster eggs. Mol. Human Reprod., 1998, 4 : 119-125.

17. FOCARELLI R., FRANCAVILLA S., FRANCAVILLA F, GIOVAMPAOLA D.C., SANTUCCI A., ROSATI F. : gp20, a sialylglycoprotein of the human capacitated sperm surface is the homologue of the leukocyte CD52 antigen: analysis of the effect of anti-CD52 monoclonal antibody (CAMPATH-1) on capacitated sperm. Mol. Human Reprod., 1999, 5 : 46-51.

18. FOCARELLI R., GIOVAMPAOLA C.D., SERAGLIA R. et al. : Biochemical and MALDI analysis of the human sperm antigen gp20, homologue of leukocyte CD52. Biochem. Biophys. Res. Commun, 1999, $258: 639-643$.

19. FOGDESTAM I., FALL M., NILSSON S. : Microsurgical epididymovasostomy in the treatment of occlusive azoospermia. Fertil. Steril., 1986, $46: 925-929$.

20. FOURNIER-DELPECH A., GUÉRIN Y. : Interactions des spermatozoïdes avec le zone pellucide. Contracept. Fertil. Steril., $1991,19: 825-832$.

21. FRENETTE G., SULLIVAN R. : Prostasome-like particles are involved in the transfer of P25g from the bovine epididymal fluid to the sperm surface. Mol. Reprod. Develop., 2001, 59 : 115-121.

22. GAGO C., SOLER C., PEREZ-SANCHEZ F., YEUNG C.H., COOPER T.G. : Effect of cetrorelix on sperm morphology during migration through the epididymis in the cynomolgus macaque (Macaca fascicularis). Am. J. Primatol., 2000, 51 : 10317.

23. GOLAN R., COOPER T.G., OSCHRY Y.et al. : Changes in chromatin condensation of human spermatozoa during epididymal transit as determined by flow cytometry. Human Reprod., 1996, $11: 1457-1462$.

24. HAMMANI-HAMZA S., DOUSSAU M., BERNARD J. et al. : Cloning and sequencing of SOB3, a human gene coding for a sperm protein homologous to an antimicrobial protein and potentially involved in zona pellucida binding. Mol. Human Reprod., 2001, $7:$ 625-632.

25. HAIDL G., BADURA B., HINSCH K.D., GHYCZY M., GAREI B.J., SCHILL W.B. : Disturbances of sperm flagella due to failure of epididymal maturation and their possible relationship to phospholipids. Human Reprod., 1993, 8 : 1070-1073.

26. HAIDL G; BADURA B., SCHILL W.B. : Function of human epididymal spermatozoa. J. Androl., 1994, 15 : 23S-27S.

27. HE X., SHEN L., BJARTELL A., MALM J., LILJA H, DAHLBÄCK, B. : The gene encoding vitamin K-dependent anticoagulant protein $\mathrm{C}$ is expressed in human male reproductive tissues. J. Histochem. Cytochem., 1995, 43 : 563-570.

28. HUTTER H., HAMMER A., BLASCHITZ A.et al. : The monoclonal antibody GZS-1 detects a maturation-associated antigen of human spermatozoa that is also present on the surface of human mononuclear blood cells. J. Reprod. Immunol., 1996, 30 : 115-32.

29. JEAN M., DACHEUX J.L., DACHEUX F., SAGOT P., LOPES P., BARRIERE P. : Increased zona-binding ability after incubation of spermatozoa with proteins extracted from spermatozoa of fertile men. J. Reprod. Fertil.,1995, $105:$ 43-48. 
30. JOW W.W., STECKEL J., SCHLEGEL P.N., MAGID M.S., GOLDSTEIN M. : Motile sperm in human testis biopsy specimens. J. Androl., 1993, $14:$ 194-198.

31. KAMEDA.K., TAKADA Y., HASEGAWA A., TSUJI Y., KOYAMA K., ISOJIMA S. : Sperm immobilizing and fertilization-blocking monoclonal antibody $2 \mathrm{C} 6$ to human seminal plasma and characterization of the antigen epitope corresponding to the monoclonal antibody. J. Reprod. Immunol., 1991, $20: 27-41$.

32. KAMEDA K., TSUJI Y., KOYOMA K., ISOJIMA S. : Comparative studies of the antigens recognised by sperm-immobilising monoclonal antibodies. Biol. Reprod, 1992, 46 : 349357.

33. KIRCHHOFF C. : Molecular characterization of epididymal proteins. Rev. Reprod., 1998, $3: 86-95$.

34. KIRCHHOFF C., KRULL N., PERA I., IVELL R. : A major mRNA of the human epididymis principal cells, HE5, encodes the leucocyte differentiation CDw52 antigen peptide backbone. Mol. Reprod. Develop., 1993, 34 : 8-15.

35. KRÄTZSCHMAR J.. HAENDLER B., EBERSPAECHER U., ROOSTERMAN D., DONNER P., SCHLEUNING W.D. : The human cysteine-rich secretory protein (CRISP) family. Primary structure and tissue distribution of CRISP-1, CRISP-2 and CRISP-3. Europ J. Biochem., 1996, $236:$ 827-836.

36. MAHONY M.C., ALEXANDER N.J. : Sites of antisperm antibody action. Human Reprod., 1991, 6 : 1426-1430.

37. MALM J., SORENSEN O., PERSSON T, et al. : The human cationic antimicrobial protein (hCAP-18) is expressed in the epithelium of human epididymis, is present in seminal plasma at high concentrations, and is attached to spermatozoa. Infec.t Immun., 2000, 68 : 4297-302.

38. MATHIEU C., GUÉRIN J.F., COGNAT M., LEJEUNE H., PINATEL M.C., LORNAGE J. : Motility and fertilizing capacity of epididymal human spermatozoa in normal and pathological cases. Fertil. Steril., 1992, $57:$ 871-876.

39. MOORE H.D.M., CURRY M.R., PENFOLD L.M., PRYOR J.P. : The culture of human epididymal epithelium and in vitro maturation of epididymal spermatozoa. Fertil. Steril., 1992, 58 : 776783.

40. MOORE, H.D.M., HARTMANN T.D., PRYOR J.P. : Development of the oocyte-penetrating capacity of spermatozoa in the human epididymis. Int. J. Androl., 1983, $6: 310-318$.

41. PATRIZIO P., ORD T., SILBER S.J., ASCH R.H. : Correlation between epididymal length and fertilization rate of men with congenital absence of the vas deferens. Fertil. Steril., 1994, 61 : 265-268.

42. ROCHWERGER L., CUASNICÚ P.S. : Redistribution of a rat sperm epididymal glycoprotein after in vitro and in vivo capacitation. Mol. Reprod. Develop., 1992, 31 : 34-41.

43. ROSS P., VIGNEAULT N., PROVENCHER S., POTIER M., ROBERTS K.D. : Partial characterization of galactosyltransferase in human seminal plasma and its distribution in the human epididymis. J. Reprod. Fertil., 1993, 98 : 129-137.

44. SANJURJO C., DAWIDOWSKY A.R., CAMEO M.S., GONZALÉZ ECHEVERRÍA F., BLAQUIER J.A. : Participation of human epididymal sperm coating antigens in fertilization. J. Androl., 1990, $11: 476-483$.

45. SCHIRREN C. : Gewebsentnahme aus dem Nebenhoden zu diagnostischen Zwecken? Andrologia, 1982, 14 ; 461-462.

46. SCHMIDT S.S., SCHOYSMAN R., STEWART B.H. : Surgical approaches to male infertility. In: Hafez, E.S.E. eds. Human Semen and Fertility Regulation in Men., 1976 : 476-493.

47. SOLER C., PÉREZ-SÁNCHEZ F., SCHULZE H., BERGMANN M., OBERPENNING F., YEUNG C., COOPER T.G. : Objective evaluation of the morphology of human epididymal sperm heads. Int. J. Androl., 2000, 23 : 77-84.

48. TEZÓN J.G., RAMELLA E., CAMEO M.S., VAZQUEZ M.H., BLAQUIER J.A. : Immunocytochemical localization of secretion antigens in the human epididymis and their association with spermatozoa. Biol. Reprod., 1985, 32 : 591-597.

49. YEUNG C.H., COOPER T.G., SENGE T. : Histochemical localization and quantification of $\alpha$-glucosidase in the epididymis of men and laboratory animals. Biol. Reprod., 1990, 42 : 669-676.

50. YEUNG C.H., COOPER T.G., BERGMANN M., SCHULZE $H$. : Organization of tubules in the human caput epididymidis and the ultrastructure of their epithelia. Am J. Anat., 1991,191 : 261-279.

51. YEUNG C.H., COOPER T.G., OBERPENNING F.; SCHULZE H., NIESCHLAG E. : Changes in movement characteristics of human spermatozoa along the length of the epididymis. Biol. Reprod., 1993, $49: 274-280$.

52. YEUNG C.H., PEREZ-SANCHEZ F., SOLER C., POSER D., KLIESCH S., COOPER T.G. : Maturation of human spermatozoa (from selected epididymides of prostatic carcinoma patients) with respect to their morphology and ability to undergo the acrosome reaction. Hum. Reprod. Update, 1997, 3 : 205-13.

53. YEUNG C.H., SCHRÖTER S., WAGENFELD A. et al. : Interaction of the human epididymal protein CD52 (HE5) with epididymal spermatozoa from men and cynomolgus monkeys. Mol. Reprod. Develop., 1997, 48 : 267-275.

54. WIESE K., HAIDL G., OPPER C., SCHILL W.B. : Erhöhte Membranrigidität bei Spermatozoen mit mangelnder Nebenhodenausreifung. Fertilität, 1996, 12 : 91-94. 